\title{
„Klatka bez drzwi i bez klucza". Analiza aspektów poznawczych i etycznych wybranych przedstawień artystycznych niepełnosprawności i osób z niepełnosprawnościami
}

\begin{abstract}
Eva Zamojska, „Klatka bez drzwi i bez klucza”. Analiza aspektów poznawczych i etycznych wybranych przedstawień artystycznych niepetnosprawności i osób z niepetnosprawnościami ["A cage without a door and a key". Analysis of cognitive and ethical aspects of selected film and literary depictions of people with disabilities]. Interdyscyplinarne Konteksty Pedagogiki Specjalnej, nr 16, Poznań 2017. Pp. 143-162. Adam Mickiewicz University Press. ISSN 2300-391X
\end{abstract}

The aim of my paper is to analyze cognitive and ethical aspects of selected literary and film depictions of disabilities. Based on theoretical and methodological assumptions of sociology of literature and critical discourse analysis I set out to demonstrate how selected literary and film works depict situations and problems with social inclusion of people with disabilities. I concentrate on two questions: 1) How do artistic creations build non-disabled people's knowledge of the social situation and position of people with disabilities? 2) What ethical problems can such depictions involve?

KEY WORDS: disability, literature, film 


\section{Wprowadzenie}

Chciałabym zaprezentować spojrzenie na problematykę niepełnosprawności i sytuacji społecznej osób z niepełnosprawnościami przez pryzmat analizy wybranych obrazów literackich i filmowych. Wydaje się oczywiste, że obrazy artystyczne osób z niepełnosprawnościami w literaturze czy filmie przyczyniają się do zmiany postaw społecznych wobec niepełnosprawności i procesów społecznej inkluzji, choćby poprzez zwrócenie uwagi na problem, wywołanie pozytywnych odczuć w odbiorcach, przełamanie utrwalonych stereotypów. Jednak pobudzanie pozytywnych afektów wobec niepełnosprawności czy osób z niepełnosprawnościami lub poznawczoodkrywcze zwrócenie uwagi na ich sytuację społeczną nie wyczerpuje możliwości interpretacji danych dzieł. W koncepcie inkluzji mieści się również uznanie podmiotowości osób $\mathrm{z}$ niepełnosprawnościami. Można więc założyć, że dzieła, których przesłanie ma charakter inkluzyjny (i to niezależnie od tego, czy jest to zabieg świadomy, czy nieświadomy oraz czy inkluzja jest przedstawiona całościowo czy fragmentarycznie), są jednocześnie dziełami realizującymi zasadę poszanowania podmiotowości osób z niepełnosprawnościami.

\section{Założenia teoretyczne i metodologiczne dyskursywnej analizy przedstawień artystycznych}

Teoretycznym i metodologicznym punktem wyjścia w podejściu do literackich i filmowych obrazów niepełnosprawności jest dla mnie konstruktywizm społeczny i krytyczna analiza dyskursu jako metoda badawcza bezpośrednio z nim związana. Powołuję się także na założenia socjologii literatury, uzasadniające wykorzystanie literatury (czy sztuki w ogóle) w charakterze przedmiotu badań poprzez wskazanie na jej przenikliwość, a czasami profetyczność 
w przedstawianiu zjawisk społecznych ${ }^{1}$. Literatura zawsze budziła zainteresowanie socjologów nawet w okresach dominacji paradygmatu pozytywistycznego i metodologii ilościowej. Stanisław Ossowski pisał np., że

W literaturze wnikliwy opis realnych lub fikcyjnych wydarzeń może poważnie wzbogacić naszą ogólną wiedzę psychologiczną lub socjologiczną przez zwrócenie uwagi na niedostrzegalne dotąd kategorie zjawisk lub na ich doniosłość, zwrócenie uwagi na nieznane dotąd zależności przyczynowe, ukazanie nowych aspektów rzeczywistości².

Prawdziwe poszerzenie pola badań nauk społecznych o artefakty takie jak literatura i sztuka nastąpiło jednak dopiero po zmianie paradygmatycznej związanej $\mathrm{z}$ tzw. zwrotem interpretatywnym $\mathrm{w}$ humanistyce ${ }^{3}$. Jeden ze zwolenników tej zmiany Michel Rouche $\mathrm{w}$ tekście Fenomenologiczny zwrot $w$ socjologii uzasadniał czynienie dzieł artystycznych przedmiotem badań w podobny sposób jak Ossowski:

Opowiadania, scenariusze, sztuki zawsze uwydatniają pewien aspekt społecznej sytuacji, w jakiej powstały, lecz mogą także [...] potęgować rysy danej, realnej sytuacji społecznej [...], których normalnie nie zauważamy i z których nie zdajemy sobie sprawy ${ }^{4}$.

Krytyczna analiza dyskursu (KDA) to metoda badań jakościowych, która koncentruje się na tekstach i ich interpretacji. Dyskurs tutaj jest rozumiany jako sposób ujmowania rzeczywistości spo-

1 Szerzej na ten temat P. Ćwikła, Kilka uwag o związku socjologii z literatura, "Studia Socjologiczne" 2006, nr 2, s. 127-158.

$2 \mathrm{~S}$. Ossowski, O osobliwościach nauk społecznych, Wydawnictwo PWN, Warszawa 1983, s. 243, za P. Ćwikła, op. cit., s. 127-158.

3 Por. C. Geertz, O gatunkach zmąconych. (Nowe konfiguracje myśli społecznej) [w:] Postmodernizm. Antologia przekładów, red. R. Nycz, Wydawnictwo Baran i Suszczyński, Kraków 1998.

${ }^{4}$ M. Rouche. Fenomenologiczny zwrot w socjologii, [w:] Fenomenologia $i$ socjologia. Zbiór tekstów, red. Z. Krasnodębski, Wydawnictwo PWN, Warszawa 1989, s. 458-474, za P. Ćwikła, op. cit, s. 18. 
łecznej w języku z akcentem na rolę języka w jej konstruowaniu. Analiza dyskursywna to analiza dyskursywnych - znaczeniowych aspektów rzeczywistości społecznej. Norman Fairclough i Anna Duszak definiują dyskurs jako semiozę - „wytwarzanie znaczeń poprzez bogactwo środków semiotycznych, obejmujących język werbalny, ale również «język wizualny» (w tym «język ciała»)"5. Przyjmują jednocześnie dwa założenia: a) że „dyskurs jest inherentnym i nieredukowalnym elementem wszystkich procesów społecznych"6 i b) że „istnieją inne elementy, które mają charakter niedyskursywny"7. Można więc za uzasadniony uznać pogląd, że w pewnym sensie rzeczywistość społeczna ze względu na wbudowany w nią aspekt dyskursywny może być postrzegana jako tekst do odczytania. Krytyczność w nazwie metody badawczej KDA oznacza świadomość ograniczeń własnej perspektywy badawczej, świadomość subiektywności interpretacji i otwarte zaangażowanie na rzecz zmiany społecznej. Istotne w podejściu KDA jest uwzględnianie kontekstu historycznego i społecznego funkcjonowania analizowanej wypowiedzi.

Twórczość artystyczna w tym układzie to specyficzny obszar produkcji znaczeń, wysoce zindywidualizowany i posiadający pewną autonomię. Autonomia ta wyraża się m.in. w zgodności $\mathrm{z}$ przez nią tworzonymi zasadami i regułami oraz $\mathrm{w}$ całym spektrum specjalistycznej "obudowy”, czyli w szeregu dyscyplin naukowych tradycyjnie się nią zajmującymi (np. estetyka, literaturoznawstwo, filmoznawstwo itp.). Przedstawiciele nauk społecznych, którzy prowadzą badania w ramach paradygmatu konstruktywistycznego i stosują metodologię jakościową, podchodzą do twórczości artystycznej w inny sposób. Abstrahując od wartości este-

${ }^{5}$ A. Duszak, N. Fairclough, Wstę: Krytyczna analiza dyskursu - nowy obszar badawczy dla lingwistyki i nauk społecznych, [w:] Krytyczna analiza dyskursu. Interdyscyplinarne podejście do komunikacji społecznej, red. A. Duszak, N. Fairclough, UNIVERSITAS, Kraków 2008, s. 8.

6 Ibidem, s. 9.

7 Ibidem. 
tycznych i specyficznych cech tekstu literackiego ${ }^{8}$ czy obrazu filmowego, patrzą na dzieło sztuki jako na wypowiedź o świecie społecznym - element dyskursu społecznego, w którym ujawniają się liczne przymusy i ograniczenia dane czasem historycznym, kontekstem społecznym oraz relacjami władzy. Dzieło sztuki nie jest postrzegane li tylko jako wyraz oryginalnej kreacji artystycznej, niezależnie od tego, że za takie może być uważane z innych punktów widzenia, lecz jako element komunikacji społecznej. Przedstawicieli nauk społecznych $\mathrm{w}$ dziele sztuki interesuje nie jego oryginalność, niepowtarzalność, lecz jego powinowactwa z określonym sposobem ujmowania rzeczywistości społecznej. Zatem od literatury (sztuki) badacz - np. socjolog, pedagog nie oczekuje wyłącznie doznań estetycznych, lecz wydobywa z niej znaczenia dotyczące problemów badawczych, które formułuje $\mathrm{w}$ ramach własnej dyscypliny naukowej. Trzeba też podkreślić, że każde odczytanie tekstu jest z natury rzeczy obarczone subiektywizmem, żadna interpretacja nigdy nie jest pełna i ostateczna, lecz te cechy są konstytutywne dla badań jakościowych $\mathrm{w}$ ogóle. Subiektywna interpretacja danego tekstu może być przecież konfrontowana $\mathrm{z}$ "subiektywnością" innego spojrzenia. Jak pisze Ruth Wodak - czołowa przedstawicielka tzw. wiedeńskiej szkoły KAD - „badacz nie ogłasza prawdy, ale proponuje interpretacje i rozwiązania problemów" ${ }^{\prime \prime}$.

Zgodnie z powyższymi założeniami artystyczne przedstawienia niepełnosprawności postrzegam jako konstrukty niosące na sobie piętno historycznych i społecznych uwarunkowań, determinujących ich kształt $w$ momencie powstania. Odczytując je, uwzględniam współczesny dyskurs edukacyjny i społeczny, kładący nacisk na

8 "Częścią tego, co rozumiemy przez utwór «literacki» jest ten wymiar, w którym to, co się mówi, trzeba ujmować w aspekcie tego, jak się to mówi. Jest to rodzaj pisania, w którym treść jest nieoddzielalna od języka, w jakim się ją przedstawia. Język jest bardziej konstytutywny dla rzeczywistości lub doświadczenia, niż stanowi po prostu środek ich wyrazu" (T. Eagleton, Jak czytać literaturę, Wydawnictwo Aletheia, Warszawa 2014, s. 15).

${ }^{9}$ Za K. Sztop-Rutkowska, Meandry dialogu. Polacy $i$ Żydzi w dyskursie prasowym międzywojennego Biategostoku, „Przegląd Socjologii Jakościowej” 2007 t. III, nr 2, s. 65. 
inkluzję/integrację społeczną osób z niepełnosprawnościami. W warstwie najogólniejszej interesuje mnie kwestia relacji dzieła artystycznego z praktyką społeczną, w tym wypadku z problemem inkluzji/integracji osób z niepełnosprawnościami.

Niepełnosprawność rozumiem zgodnie z podejściem konstruktywistycznym oraz z założeniami społecznego modelu niepełnosprawności jako cechę relacji osoby z otoczeniem, nie zaś cechę samej osoby.

To nie obiektywne, fizyczne i psychiczne ograniczenia sprawnego działania są powodem niemożności uczestnictwa w różnych aktywnościach życiowych przez osoby nimi dotknięte, lecz sposób ich organizacji społecznej, który ustanawia bariery dostępności niemożliwe do pokonania przez nie ${ }^{10}$.

Uznanie niepełnosprawności za konstrukt społeczny oznacza, iż w warunkach współczesnych społeczeństw rozwiązywanie problemów niepełnosprawności musi uwzględnić działanie na poziomie makrospołecznym, tworzenie właściwych rozwiązań instytucjonalnych i włączenie osób niepełnosprawnych w zwykłe mechanizmy życia społecznego, łącznie z gospodarką, polityką czy kulturą ${ }^{11}$.

Wieloznaczne pojęcia inkluzja i integracja stosuję w trzech różnych kontekstach, które wpływają na różne ich rozumienie. Inkluzję stosuję najczęściej w rozumieniu szerokim - jako pojęcie odnoszące się do procesów uspójnienia społecznego, obejmujące polityki państwowe na różnych polach życia społecznego, działania instytucjonalne oraz zmianę postaw i zachowań podmiotów społecznych, których całościowym skutkiem powinno być równe traktowanie wszystkich jednostek, niezależnie od ich cech szczególnych, eliminacja marginalizacji i wykluczenia społecznego. Synonimem tak rozumianej inkluzji może być pojęcie integracja - oba pojęcia, choć dotyczą przede wszystkim zmiany statusu społecznego grup zmarginalizowanych, odnoszą się do jakościowej zmiany całego społeczeń-

10 B. Gąciarz, Przemyśleć niepetnosprawność na nowo. Od instytucji państwa opiekuńczego do integracji i aktywizacji społecznej, „Studia Socjologiczne” 2014, 2 (213), s. 21-22.

11 B. Gąciarz, op. cit., s. 28. 
stwa, ponieważ odrzucają dychotomię normatywności/nie normatywności (ewentualnie normalności/nienormalności) oraz zrywają z wyobrażeniem o uprawnieniu grupy dominującej do wprowadzania rozwiązań społecznych, do których mniejszości powinny się dostosować. Drugie zastosowanie i rozumienie pojęcia inkluzja ma odniesienie wyłącznie do osób z niepełnosprawnościami i oznacza zmianę ich dotychczasowego społecznego funkcjonowania. Inkluzja - proces włączania osób z niepełnosprawnościami do głównego nurtu życia społecznego - $\mathrm{w}$ tym kontekście jest jednym $\mathrm{z}$ warunków integracji społecznej wszystkich członków społeczeństwa. Trzeci kontekst związany jest z konsekwentnie rozdzielnymi typami edukacji (szkoły) przeznaczonymi dla osób z niepełnosprawnościami, bo opartymi na różnych modelach niepełnosprawności, a także na różnych założeniach aksjologicznych - tj. edukacji integracyjnej i edukacji inkluzyjnej ${ }^{12}$.

\section{Analiza wybranych artystycznych przedstawień niepełnosprawności}

Głównym przedmiotem moich analiz są dwa współczesne przedstawienia artystyczne, których bohaterami są osoby z porażeniem mózgowym. Chodzi o film polskiej produkcji "Chce się żyć"13 z 2013 r. w reżyserii Macieja Pieprzycy oraz książkę dla nastolatków amerykańskiej autorki Sharon Mills Draper pt. Tylko w mojej głowie ${ }^{14}$. Wybrałam je ze względu na przedstawienie jednego rodzaju niepełnosprawności, ale też ze względu na możliwość wskazania

12 Por. G. Szumski, Edukacja inkluzywna - geneza, istota, perspektywy, „Kwartalnik Pedagogiczny" 2006 nr 1.

13 "Chce się żyć" - polski film fabularny w reżyserii Macieja Pieprzycy. Główną rolę Mateusza Rosińskiego zagrał Dawid Ogrodnik (w rolę Mateusza w dzieciństwie wcielił się Kamil Tkacz). Premiera filmu odbyła się 11 października 2013 roku. (Wikipedia, https://pl.wikipedia.org/wiki/Chce_si\%C4\%99_\%C5\%BCy\%C4\%87 [dostęp: 30.05.2017].

14 S.M. Draper, Tylko w mojej głowie, Wydawnictwo Linia, Ożarów Mazowiecki 2016. 
różnych sposobów konstruowania niepełnosprawności oraz podmiotowości osób z niepełnosprawnościami, które, w moim przekonaniu, są znaczące dla odbioru tych dzieł i w konsekwencji dla rozumienia przez widzów, czytelników sytuacji społecznej takich osób. Analizę tych współczesnych obrazów poprzedza próba ogólniejszej refleksji na temat przedstawień niepełnosprawności w literaturze i filmie, ilustrowana kilkoma wybranymi przykładami literackimi i filmowymi. Zaznaczam, iż ma ona charakter wstępnego rozpoznania i służy tylko podstawowemu - siłą rzeczy pobieżnemu i schematycznemu - uporządkowaniu przedstawień artystycznych niepełnosprawności $w$ literaturze i filmie. Mój punkt widzenia $\mathrm{w}$ podejściu do wszystkich analizowanych przedstawień to punkt widzenia osoby pełnosprawnej. Nie ma $w$ nim doświadczenia niepełnosprawności, jest on zbieżny z perspektywą pełnosprawnych widzów i czytelników, do których dzieła te, jak sądzę, są przede wszystkim adresowane.

W przedstawionych poniżej analizach wybranych artystycznych przedstawień niepełnosprawności i osób z niepełnosprawnościami, koncentruję się na poznawczych i etycznych aspektach ich konstrukcji. Interesuje mnie:

- jakie rozumienie zjawiska niepełnosprawności zawierają analizowane przedstawienia?

- jakie rozumienie zjawiska inkluzji/integracji społecznej osób $\mathrm{z}$ niepełnosprawnościami zawierają analizowane przedstawienia? - czy i w jaki sposób analizowane przedstawienia konstruują podmiotowość osób z niepełnosprawnościami?

\section{Dwie kategorie artystycznych przedstawień niepełnosprawności}

Kiedy się przyjrzymy artystycznym przedstawieniom osób $\mathrm{z}$ niepełnosprawnościami $\mathrm{w}$ literaturze czy filmie, możemy dostrzec, abstrahując od podziałów gatunkowych i formalnych, zasadniczo dwie kategorie, dwa schematy takich przedstawień. 
Pierwszy schemat ujawnia się w powieściach (literaturze) i w filmach niejako przy okazji wypowiedzi artystycznej na inny temat. Osoby niepełnosprawne $\mathrm{i}$ ich problemy nie stanowią $\mathrm{w}$ nich pierwszoplanowego wątku i nie są głównym tematem dzieła. Czasami tego rodzaju przedstawienie daje mimowolnie wyobrażenie o rzeczywistej sytuacji społecznej osób z niepełnosprawnościami, właśnie dlatego, iż jest konstruowane bez specjalnych założeń co do jego poprawności, a także bez intencji zaangażowanego działania na ich rzecz. Jeśli mamy do czynienia z dziełami sztuki o najwyższym poziomie artystycznym, nawet ograniczona przestrzeń wątku pobocznego czy drugo-, a nawet trzecioplanowej postaci nie przeszkadzają w tym, by stworzyć udaną wypowiedź na temat osoby niepełnosprawnej, czyli obraz niewyidealizowany, a jednocześnie wyrażający uniwersalne wartości etyczne.

Przytoczę dwa przykłady pochodzące z różnych epok historycznych oraz reprezentujące różne formy wypowiedzi artystycznych. Łączy je to, że są dziełami uznawanymi za ponadczasowe i są powszechnie znane. Dlatego dobrze się nadają do rozważań na temat powyższej tezy.

W pierwszej połowie XIX w. (w roku 1831) Victor Hugo napisał powieść Katedra Matki Bożej w Paryżu, w której wykreował postać zniekształconego fizycznie i niewładającego mową dzwonnika Quasimodo. Historia $\mathrm{z}$ jednej strony obrazowała średniowieczny lęk i wstręt wobec fizycznej i intelektualnej nienormatywności. Z drugiej strony relacja empatycznej przyjaźni dwóch „wyrzutków” społecznych - pięknej Cyganki Esmeraldy i fizycznie odstręczającego, lecz posiadającego, mówiąc słowami Kanta, wewnętrzne prawo moralne, Quasimodo, nawiązując do archetypu pięknej i bestii, wyrażała z gruntu oświeceniowe przekonanie, że nie wygląd i umiejętności komunikacji (cechy przypisane) decydują o wartości człowieka. Hugo jednak nie napisał powieści po to, by podnieść problem niepełnosprawności fizycznej i intelektualnej. Posłużył się kostiumem średniowiecznym, by opowiedzieć się po stronie społecznie zmarginalizowanych warstw miejskiej biedoty wegetującej w centrum bogatego miasta, do której należą zarówno Esmeralda, jak i Quasimodo. 
Drugi przykład to film Miloša Formana, adaptacja powieści Kena Keseya, Lot nad kukułczym gniazdem. Ken Kesey, amerykański pisarz, beatnik i hippis, napisał powieść (z roku 1962) o wymowie antysystemowej; był to wyraz jego protestu przeciwko wszelkim formom społecznego i mentalnego zniewolenia jednostki. Miloš Forman, emigrant z komunistycznej Czechosłowacji po 1968 r., w filmowej adaptacji przesunął lekko znaczenie powieści tak, by ze szpitalnego oddziału psychiatrycznego z jego demoniczną zarządzającą siostrą Ratched stworzyć metaforę systemu totalitarnego. W jednym i drugim przypadku chodzi o relację na linii jednostka system. Bogusław Sułkowski podkreślał, iż

Lot nad kukułczym gniazdem nie jest paszkwilem na psychiatrów tylko. Na ekstremalnym przykładzie studiuje się tu ogólniejsze prawa organizacji życia zbiorowego, reguły przejścia od konformizmu do niezależności, mechanizmy kontroli i przyporządkowywania sobie ludzi ${ }^{15}$.

To, że opresji poddawani są pacjenci z różnymi zaburzeniami psychicznymi i prawdopodobnie także $z$ niepełnosprawnością intelektualną (postać rdzennego mieszkańca Ameryki, przezywanego Wodzem) jest $\mathrm{w}$ zasadzie nieistotne $\mathrm{z}$ punktu widzenia ogólnej wymowy dzieła. Jednak istotnym wątkiem fabularnym jest integracja grupy nienormatywnych intelektualnie i psychicznie pacjentów oddziału pod przewodnictwem i z inspiracji pełnosprawnego i zdrowego psychicznie buntownika McMurphy'ego. Ta integracja jest jedynym budującym elementem opowieści. McMurphy'emu udaje się osiągnąć to, czego nie osiąga farmakologia, elektrowstrząsy, a zwłaszcza przemocowy model relacji personel medyczny - pacjent. Prawdziwą terapią dla pacjentów jest bezpośredniość i „kumplowskie" relacje w grupie, zapoczątkowane wraz z przyjściem na oddział McMurphy'ego. Być może ten wzór relacji, pozbawiony stereotypowego lękowego podejścia do pacjentów psychiatrycz-

${ }^{15}$ B. Sułkowski, Hamletyzowanie nasze. Socjologia sztuki, polityki i codzienności, Wydawnictwo Uniwersytetu Łódzkiego, Łódź 1993, s. 140; za P. Ćwikła, op. cit., s 127-158. 
nych i paternalizmu ekspertów, należałoby uznać za prekursorski $\mathrm{w}$ rozumieniu współczesnych reguł inkluzji społecznej osób z niepełnosprawnościami, i nie tylko ich.

Podsumowując ten wątek, chciałabym podkreślić, iż dzieła sztuki z tej kategorii pokazują problemy osób niepełnosprawnych nie jako problemy szczególne, lecz jako aspekt problemu ogólniejszego - być może bardziej podstawowego konfliktu społecznego pomiędzy posiadającymi władzę i podporządkowanymi tej władzy. W praktyce ekspresji artystycznej mamy tutaj do czynienia z czymś na podobieństwo spontanicznej inkluzji społecznej i, uwzględniając czasy powstania książki i filmu, z pewnego rodzaju antycypacją współczesnych rozwiązań inkluzyjnych. Chodzi o włączenie problemów osób niepełnosprawnych do problemów pozostałych zmarginalizowanych i też przez to cierpiących grup społecznych. Można powiedzieć, iż racje moralne wszystkich opresjonowanych i zmarginalizowanych, w tym osób z niepełnosprawnościami, wyrażające się $\mathrm{w}$ postaci roszczenia do traktowania wszystkich jako pełnoprawnych i zasadniczo wolnych jednostek, znajdują się tutaj na pierwszym planie, choć specyfika poszczególnych grup opresjonowanych jest mniej widoczna.

Z powyższym rozpoznaniem koresponduje zestawienie dwóch różnych historycznie istniejących modeli traktowania niepełnosprawności i osób z niepełnosprawnościami - charakterystycznego dla wcześniejszych okresów historycznych modelu indywidualnego i bardziej współczesnego modelu społecznego.

Model indywidualny przyjmuje za oczywistość istniejące mechanizmy społeczne i za cel stawia sobie dostosowanie do niego osoby niepełnosprawnej, nie pozostawiając jej w tym względzie żadnego wyboru. Jedynym celem działań, zewnętrznym wobec samych osób niepełnosprawnych, są postawy ludzkie, subiektywne odnoszenie się do nich i ich obecności w otoczeniu społecznym. W modelu społecznym z kolei mechanizmy społeczne podlegają krytyce, są podważane jako przyczyny powodujące problematyzację egzystencji osób niepełnosprawnych. [...] Osoby niepełnosprawne są postrzegane jako pełnoprawne podmioty działania. [...] $\mathrm{W}$ związku z tym celem polityki 
wobec nich musi być zapewnienie im możliwości skorzystania z praw podmiotowych ${ }^{16}$.

W solidarności sprawnego bohatera i pacjentów oddziału psychiatrycznego i ich wspólnym buncie przeciwko opresji w Locie nad kukutczym gniazdem można więc dostrzec także zalążek przekształcenia indywidualnego modelu w podejściu do niepełnosprawności w model społeczny, który jest podstawą współczesnych działań inkluzyjnych.

Druga kategoria/schemat przedstawień artystycznych koncentruje się wyłącznie na osobach z niepełnosprawnościami, czyniąc ich specyficzną sytuację głównym tematem wypowiedzi twórców (np. „Rain Man” Barry Levinsona, "Człowiek słon”" Davida Lyncha, „Forrest Gump" Roberta Zemeckisa). Zazwyczaj obrazy te konstruowane są w taki sposób, by przełamać stereotypy lub innego rodzaju utrwalone i zmitologizowane wyobrażenia na temat osób z jakimś rodzajem niepełnosprawności, pokazać je jako osoby nie tylko warte współczucia, empatii i pomocy, lecz jako osoby, których potencjał w sprzyjających warunkach może być rozwijany z pożytkiem dla nich i dla wszystkich członków społeczeństwa. Takie podejście jest cenne poznawczo, przybliża specyficzne problemy osób z konkretną niepełnosprawnością, lecz wydaje się, że w przypadku niektórych współcześnie powstających dzieł samo przełamywanie stereotypów, wywoływanie współczucia czy empatii jest celem niewystarczającym i niekiedy może budzić różnego rodzaju wątpliwości etyczne. Na problemy tego rodzaju chciałabym zwrócić uwagę w ostatniej części tego tekstu.

\section{Konstrukcja porażenia mózgowego i osób z porażeniem mózgowym $w$ filmie "Chce się żyć" i w książce Tylko w mojej głowie}

Poddaję analizie dwa obrazy artystyczne z ostatniego czasu film polskiej produkcji „Chce się żyć” z 2013 r. reżysera Macieja

16 B. Gąciarz, op. cit., s. 27. 
Pieprzycy oraz książkę dla nastolatków amerykańskiej autorki Sharon M. Draper pt. Tylko w mojej głowie17. Oba te dzieła to obrazy fikcyjne, głównym tematem obu jest życie i funkcjonowanie społeczne osób z porażeniem mózgowym. Z książki Tylko w mojej głowie zaczerpnęłam metaforę „klatka bez drzwi i bez klucza”, która, moim zdaniem, trafnie oddaje sytuację społeczną osób dotkniętych tym rodzajem niepełnosprawności. Zestawienie tych konkretnych dzieł jest przeze mnie zamierzone nie tylko ze względu na ten sam rodzaj niepełnosprawności i bliskość czasu, w którym toczą się obie opowieści. Także pod względem konstrukcji narracyjnej oba dzieła są do siebie podobne. To subiektywne opowieści osób sprawnych intelektualnie, lecz ze względu na wrodzoną niepełnosprawność fizyczną nie mogących się komunikować z otoczeniem. Sytuacja osób z podobnym problemem w odmiennych społecznie i kulturowo środowiskach może być wykorzystana jako źródło wiedzy do porównań rozwiązań instytucjonalnych i postaw wobec osób z porażeniem mózgowym w Polsce i w Stanach Zjednoczonych. Jednak w konfrontacji tych dwóch obrazów artystycznych interesuje mnie bardziej ich odmienna wymowa etyczna. O ile lektura książki S.M. Draper nie wywołuje rozterek natury etycznej, które wynikałyby z samej konstrukcji powieści, o tyle film M. Pieprzycy mimo bezsprzecznie wysokiego poziomu profesjonalizmu - kreacji aktorskich i pracy reżysera - nie jest pod tym względem jednoznaczny. Tę tezę spróbuję udowodnić.

Film fabularny (fikcja) Chce się żyć opowiada historię Mateusza z porażeniem mózgowym. Jest on typową ofiarą błędnych diagnoz medycznych i braku systemowych rozwiązań w późnym PRL, na skutek czego przez większość swojego życia postrzegany jest jako niezdolny do myślenia i nieedukowalny i spędza życie w specjalnym ośrodku. W jego otoczeniu znajdują się osoby, które są przekonane, że Mateusz rozumie i reaguje prawidłowo (są to przede wszystkim rodzice), lecz dopiero przypadkowe spotkanie ze "światłą" lekarką powoduje, że Mateusz otrzymuje w miarę adekwatną

17 S.M. Draper, op. cit. 
pomoc w pokonywaniu bariery komunikacyjnej - język logograficzny Blissa. Historia opowiedziana $\mathrm{w}$ filmie oddziałuje przede wszystkim na emocje widzów pełnosprawnych. Temu służy zabieg zderzenia dwóch narracji - obiektywnej ekranowej - która dotyczy tego, jak reaguje i postępuje otoczenie Mateusza, nieświadome jego uczuć i myśli oraz subiektywnej - samego Mateusza, który komentuje z offu własną historię przedstawioną na ekranie, zwracając się bezpośrednio do widza. Doceniając emocjonalne walory filmu i jego zasługi dla popularyzacji tematyki (uczynienia widzialnymi osób z porażeniem mózgowym), nie można abstrahować od kontekstu przed i po powstaniu filmu, tym bardziej, że nagłośniony w mediach stał się w zasadzie elementem marketingowej promocji. Kontekst ten jednak zmienia przesłanie etyczne tego dzieła. Maciej Pieprzyca nakręcił fikcję, jednak za główną inspirację posłużyła mu historia prawdziwej osoby - Przemka Chrzanowskiego, o którym wcześniej i z jego udziałem reżyserka Ewa Pięta nakręciła film dokumentalny pt. Jak motyl (2004 r.). Twórcy filmu Chce się żyć przed jego powstaniem spotkali się z Przemkiem Chrzanowskim. Doniesienia prasowe po powstaniu filmu mówiły jednak o niezbyt dobrym samopoczuciu Przemka, który czuł się przez filmowców wykorzystany i zapomniany. Cały czas posługuje się pismem Blissa i przebywa w specjalistycznym ośrodku ${ }^{18}$. Reżyser odrzuca wszelkie zarzuty, mówiąc:

Ja robiłem film fabularny, a nie reportaż interwencyjny. Jak ja mogłem cokolwiek obiecać? Co najwyżej to, że zrobię dobry film na trudny temat. To nie jest żaden samograj, to nie jest film komercyjny. Jak można mówić komercyjnie o niepełnosprawności? Mówiłem tylko, że jak ten film się uda, to ludzie będą rozmawiali o tym problemie ${ }^{19}$.

Oto paradoks - twórcy robią film o niepełnosprawności, kierując się m.in. motywacją nagłośnienia problemu niepełnosprawności,

18 http:/ / natemat.pl/79681,filmowcy-mnie-wykorzystali-bohater-chce-sie-zycoskarza-tworcow-filmu [dostęp: 21.03.2017].

${ }^{19}$ http:/ / natemat.pl/79729,maciej-pieprzyca-niczego-nie-obiecywalem-tworcafilmu-chce-sie-zyc-odpowiada-na-zarzuty-bohatera-filmu [dostęp: 21.03.2017]. 
lecz film przynosi sławę i nagrody twórcom, nie wpływając na zmianę sytuacji tego/tych, w którego/których imieniu powstał. Problem etyczny, który tu podnoszę, ma oczywiście szersze odniesienie, dotyczy traktowania osób, których historie życiowe stają się inspiracją dla twórczości artystycznej, zwłaszcza filmowej, o czym niżej, przy czym jest on problemem nawet (a być może przede wszystkim) wtedy, kiedy one same wyrażają na to zgodę lub współpracują z twórcami. Czy w takiej sytuacji finalny efekt tak powstającego dzieła jest wyłączną zasługą jego twórców? Czy roszczenia tzw. inspiratora do choćby cząstkowego udziału w uznaniu dla finalnego efektu twórczości artystycznej nie należałoby uznać za uprawnione? A czy miarą szczerości intencji twórców, zwłaszcza wtedy, kiedy ich dzieło ewidentnie angażuje się po stronie podmiotowego traktowania osób z niepełnosprawnością, nie powinna być szczególna troska o podmiotowe traktowanie osoby, której historia stała się inspiracją dla powstania dzieła - czyli symboliczne jej dowartościowanie i realne wsparcie w rozwiązywaniu jej problemów życiowych?

Innym problemem, który wiąże się z tego rodzaju konstrukcją filmu fabularnego, jest niemożliwa do pokonania luka pomiędzy reprezentacją a reprezentowanym. Reprezentacja w warstwie poznawczej jest uogólnieniem, syntetycznym wyrazem wielu jednostkowych przypadków, żaden jednostkowy przypadek nie odnajduje się w pełni w tym, co lub kto go reprezentuje. W warstwie etycznej problem reprezentacji i reprezentowanego(-ych) wyraża się w pytaniu, czy podmiotowość tych, w których imieniu się przemawia, nie doznaje w ten sposób uszczerbku? Jest to problem analogiczny do tego, który w kontekście kolonialnym stawia Gayatri Chakravorty Spivak, pytając "Czy podporządkowani inni mogą przemówić?" 20. Parafrazując to pytanie na potrzeby tego tekstu, mogłoby ono brzmieć tak: „Czy niepełnosprawni skazani są na to, by reprezentował ich pełnosprawny?". Tę kwestię w inny sposób formułuje autor wnikliwej analizy filmu Pieprzycy Bartosz Zając:

${ }^{20}$ G.C. Spivak, Czy podporządkowani inni moga przemówić?, „Krytyka Polityczna” 2011, 24-25: 196-239. 
Dla kogo takie filmy powstają - czemu służy opowiedzenie tych historii $\mathrm{w}$ taki a nie inny sposób? [...] Reżyser posłużył się aktorami i stworzył fikcję rządzącą się takimi samymi prawami jak w każdym innym filmie fabularnym. Nie wykonał pracy pozwalającej pokonać barierę komunikacyjną między nami a prawdziwym bohaterem filmu. Nie dał nam też okazji zetknięcia się z człowiekiem, który na co dzień ukrywany jest przed naszym wzrokiem za drzwiami instytucji odosobnienia. Jeśli funkcją tego i podobnych filmów jest „oddanie głosu” ludziom, którym do tej pory odmawiano mówienia własnym głosem, których ukrywano na marginesach społecznych, to zmiana tej sytuacji wymaga otwarcia kina na ich obecność - przede wszystkim na poziomie obsadowym ${ }^{21}$.

S.M. Draper w swojej książce stosuje identyczny jak M. Pieprzyca zabieg konstrukcyjny, czyli „oddaje głos” osobie z porażeniem mózgowym, nastolatce Mellody. Nie ma tu podwójnej narracji mamy do czynienia wyłącznie $z$ narracją pierwszoosobową. Fabuła tej opowieści jest bardzo podobna do Chce się żyć - jest to historia usilnych dążeń bohaterki, by wydostać się na zewnątrz „klatki bez drzwi i bez klucza", co jej się z pomocą rodziców i innych życzliwych dorosłych w końcu udaje. Jednak w tym wypadku nie mamy wątpliwości, iż Mellody jest postacią fikcyjną i nie ma odniesienia do żadnej konkretnej osoby, a raczej - ma odniesienie do wszystkich. Jej postać jest syntetycznym obrazem wielu możliwych przypadków, lecz zarazem żadnego autentycznego przypadku. Nie stanowi reprezentacji. W sensie poznawczym mamy do czynienia raczej z konstrukcją "typu idealnego" (w rozumieniu Maxa Webera), co z pewnością wynika także $\mathrm{z}$ różnic pomiędzy literaturą i filmem jako różnymi formami ekspresji artystycznej. Literatura operuje słowem - symbolem, wymagającym przetworzenia na obraz przez każdego konkretnego czytelnika, w rezultacie czytelnicza percepcja przekłada słowo na nieskończoną wielość obrazów. Istotą filmu jest dosłowność, konkret „obrazu”, narzucenie obrazu - jed-

${ }^{21}$ B. Zając, Etyka fabularzysty. Uwagi na marginesie "Chce się żyć” Macieja Pieprzycy, http://edukacjafilmowa.pl/materialy-edukacyjne/analizy-filmow/item/545-chce-si \% C4\%99-\% C5\% BCy\%C4\%87 [dostęp: 18.03.2017]. 
nego, konkretnego - wszystkim widzom, stąd m.in. sygnalizowany problem reprezentacji (aktor zawsze „reprezentuje” inną osobę), choć w przypadku filmu Chce się żyć ten problem otrzymuje dodatkowy wymiar, jak próbowałam wykazać, wynikający z inspiracji twórców filmu życiem autentycznej postaci.

W warstwie poznawczej pomiędzy polskim filmem a amerykańską powieścią są istotne różnice. Film nie zajmuje się problemem inkluzji społecznej osób z porażeniem mózgowym, choć historycznym tłem biografii głównego bohatera jest nie tylko zmiana ustrojowa w Polsce, ale także istotne zmiany w traktowaniu niepełnosprawności zarówno w teorii, jak i w praktyce edukacyjnej. Filmowy Mateusz w "Chce się żyć” w zasadzie całe życie spędza w specjalnym ośrodku, nie ma tu nawet znaku, że mógłby się kształcić i żyć gdzie indziej. Jego próby nawiązania partnerskich relacji z wolontariuszką kończą się niepowodzeniem. Innych prób nie podejmuje, wycofując się do bezpiecznego kręgu znajomych z ośrodka i bezpiecznej roli bycia jego podopiecznym.

Powieść Tylko w mojej głowie poszerza naszą wiedzę o doświadczenia szkolnej integracji czy inkluzji osób z niepełnosprawnościami. Bohaterka powieści wyrasta w kochającej się rodzinie, ma młodszą pełnosprawną siostrę, jest wspierana przez sąsiadkę - opiekunkę i wolontariuszkę - studentkę, kształci się w ogólnodostępnej szkole. Powieść pokazuje realia edukacji integracyjnej i inkluzyjnej w Stanach Zjednoczonych w dwóch aspektach: kształcenia dzieci niepełnosprawnych w szkole ogólnodostępnej oraz relacji rówieśniczych w klasie inkluzyjnej. Integracja w szkole Mellody polega na tym, że dzieci z różnymi rodzajami niepełnosprawności uczą się $\mathrm{w}$ osobnych "specjalnych" klasach, tylko niektóre zajęcia odbywają się w klasach ogólnodostępnych, poza tym wszyscy spędzają przerwy między zajęciami na szkolnym podwórku (raczej w osobnych grupach). Bohaterka książki jest ponadprzeciętnie inteligentna i jednocześnie głęboko upośledzona fizycznie. Do komunikacji jednak używa specjalnego komputera, który pomaga jej w przekonaniu otoczenia, że jest zdolną i inteligentną dziewczynką. Niewątpliwy sukces osobisty i edukacyjny bohaterki nie przekłada się jednak na 
jej pozycję społeczną $\mathrm{w}$ żadnej $\mathrm{z}$ grup rówieśniczych, w których przebywa. Mellody w klasie „specjalnej” się nudzi, w klasie ogólnodostępnej doznaje odrzucenia ze strony sprawnych rówieśników. Jednak konstrukcja opowieści jest przewrotna. Na samym końcu znajduje się sugestia, iż to właśnie Mellody w obliczu niepowodzeń $\mathrm{w}$ relacjach z rówieśnikami postanawia chwycić za pióro i opisać własną historię wydobywania się $\mathrm{z}$ „,klatki” niepełnosprawności i że książka, którą właśnie przeczytaliśmy, jest jej autorstwa. Ten zabieg konstrukcyjny jest niezwykle optymistyczny, ponieważ retrospektywnie rzuca nowe światło na historię Mellody, ale też wskazuje obszar indywidualnej aktywności twórczej jako możliwego kierunku rozwoju i umacniania tożsamości społecznej.

\section{Zakończenie}

Zestawiając dwa współczesne artystyczne obrazy osób z porażeniem mózgowym, tak z pozoru podobne, poruszamy się, mówiąc metaforycznie, w dwóch różnych światach. Zarówno film, jak i książka dotykają problemu relacji przyjacielskich i miłosnych pomiędzy osobami z niepełnosprawnościami i osobami pełnosprawnymi. Rzeczywiście niezależnie od tego, czy społeczeństwo ułatwia dostęp do życia społecznego osobom z niepełnosprawnością, ich integracja społeczna $\mathrm{w}$ znaczeniu nieformalnych więzi napotyka na bariery. Jednak $w$ reakcji filmowego bohatera i bohaterki książki na tego rodzaju bariery ujawnia się znacząca różnica, która wiele mówi, jak sądzę, także o rozumieniu niepełnosprawności przez twórców tych dzieł.

Książka amerykańskiej autorki zajmuje się wprost problemem inkluzji osób z porażeniem mózgowym. Pokazuje, że aktualnie w Stanach Zjednoczonych nie jest to problem pokonania bariery komunikacyjnej ani edukacji inkluzyjnej takich osób. Zwraca uwagę przede wszystkim na nierozwiązany (i pewnie najtrudniejszy do rozwiązania) problem inkluzji/integracji społecznej na poziomie nieformalnych relacji rówieśniczych - czy i jak możliwe jest włącze- 
nie osoby z niepełnosprawnością w relacje przyjaźni i miłości ze sprawnymi rówieśnikami?

W odróżnieniu od książki film „Chce się żyć” poznawczo nie przynosi nowych pytań ani nowych rozwiązań, jest skoncentrowany głównie na wywoływaniu efektów emocjonalnych u pełnosprawnych widzów - współczucia, empatii, podziwu dla wysiłków bohatera. Pomieszanie porządków kreacji i autentyzmu w konstrukcji głównego bohatera filmu może budzić wątpliwości etyczne. Być może film odzwierciedla rzeczywistą sytuację osób z porażeniem mózgowym w Polsce, którym status socjoekonomiczny nie pozwala na więcej niż na komunikację za pomocą języka logograficznego i spędzenie życia w ośrodku. Jeśli tak jest, optymistyczny tytuł filmu należałoby utożsamić wyłącznie $\mathrm{z}$ indywidualnym sukcesem bohatera $\mathrm{w}$ pokonaniu wrodzonych trudności komunikacyjnych i w uzyskaniu tożsamości społecznej. Nic w filmie nie wskazuje na to, że te indywidualne osiągnięcia mogą się przełożyć na zmianę pozycji społecznej bohatera, a przede wszystkim, że mogą być podstawą aktywności, która by poszerzyła i pogłębiła jego kontakty społeczne. Z tego względu wydaje mi się, że ten sposób przedstawiania problemu tej konkretnej niepełnosprawności zamyka twórców i widzów w kręgu współczucia, pomagania i kultury zależności - w „klatce” indywidualnego modelu niepełnosprawności.

\section{Bibliografia}

Ćwikła P., Kilka uwag o zwiazku socjologii z literatura , „Studia Socjologiczne” 2006, nr 2. Eagleton T., Jak czytać literaturę, Wydawnictwo Aletheia, Warszawa 2014.

Geertz C., O gatunkach zmaconych. (Nowe konfiguracje myśli społecznej), [w:] Postmodernizm. Antologia przekładów, red. R. Nycz, Wydawnictwo Baran i Suszczyński, Kraków 1998.

Krytyczna analiza dyskursu. Interdyscyplinarne podejście do komunikacji spotecznej, red. A. Duszak, N. Fairclough, UNIVERSITAS, Kraków 2008.

Ossowski S., O osobliwościach nauk społecznych, Wydawnictwo PWN, Warszawa 1983.

Rouche M., Fenomenologiczny zwrot w socjologii, $[w]$ Fenomenologia i socjologia. Zbiór tekstów, red. Z. Krasnodębski, Wydawnictwo PWN, Warszawa 1989. 
Gąciarz B., Przemyśleć niepetnosprawność na nowo. Od instytucji państwa opiekuńczego do integracji i aktywizacji spotecznej, „Studia Socjologiczne” 2014, 2(213).

Szumski G., Edukacja inkluzywna - geneza, istota, perspektywy, „Kwartalnik Pedagogiczny" 2006, nr 1 .

Sułkowski B., Hamletyzowanie nasze. Socjologia sztuki, polityki i codzienności, Wydawnictwo Uniwersytetu Łódzkiego, Łódź 1993.

Spivak G.C., Czy podporządkowani inni moga przemówić?, „Krytyka Polityczna” 2011.

Sztop-Rutkowska K., Meandry dialogu. Polacy i Żydzi w dyskursie prasowym międzywojennego Białegostoku, „Przegląd Socjologii Jakościowej” 2007, t. III, nr 2.

Zając B., Etyka fabularzysty. Uwagi na marginesie "Chce się żyć" Macieja Pieprzycy, http://edukacjafilmowa.pl/materialy-edukacyjne/analizy-filmow/item/545chce-si $\%$ C4\%99-\%C5\%BCy\%C4\%87 [dostęp: 18.03.2017].

Draper S.M., Tylko w mojej głowie, Wydawnictwo Linia, Ożarów Mazowiecki 2016.

Netografia

Wikipedia, https://pl.wikipedia.org/wiki/Chce_si\%C4\%99_\%C5\%BCy\%C4\%87 [dostęp: 30.05.2017].

http://natemat.pl/79681,filmowcy-mnie-wykorzystali-bohater-chce-sie-zyc-oskarzatworcow-filmu [dostęp: 21.03.2017].

http:/ / natemat.pl/79729,maciej-pieprzyca-niczego-nie-obiecywalem-tworca-filmuchce-sie-zyc-odpowiada-na-zarzuty-bohatera-filmu [dostęp: 21.03.2017]. 